\title{
Economics of Green Design and Environmental Sustainability
}

\author{
Austin C. Otegbulu PHD, FNIVS RSV \\ Department of Estate Management, Faculty of Environmental Sciences \\ University of Lagos, Nigeria \\ E-mail: Austinotegbulu@Yahoo.Com
}

Received: November 30, 2010

Accepted: January 28, 2011

doi:10.5539/jsd.v4n2p240

\begin{abstract}
In spite of the huge environmental and energy problem in Nigeria, designers have not seen the need for a shift from their traditional method of designing buildings. The purpose of this paper is to highlight the need for green and sustainable design in Nigeria using Lagos as a case study with focus on the effects of green design on environmental sustainability including its economic implication and occupiers preferences with respect to building components and services to ascertain the level of their appreciation of green elements.

Questionnaires were distributed to various groups which include; residents (households) at Dolphin and Abraham Adesanya estates Lagos and also 1040 households in 8 metropolitan local government areas of Lagos to determine the extent of power (electricity) problem and the use of private generators in the city.

Findings from the study show that flooding and loss of property arise from lack of green and sustainable design. It was also found out that due to poor electricity supply, households resort to informal power supply which contributes to global warming.

The paper recommends that there is need for a holistic adoption of green design as lack of it has been observed to be adverse to efficiency in buildings and environmental sustainability in Lagos.
\end{abstract}

Keywords: Ecological design, Environmental sustainability, Green building, Sustainability

\section{Introduction}

The term "green" and "sustainable" design is often used interchangeably though there are shades of meaning implied by each. Green building measures can lead not only to lower building operating expenses through reduced utility and waste disposal cost, but also to lower ongoing building maintenance cost ranging from salaries to suppliers. The emphasis is on efficiency. Sustainability is a goal that allows for the continuing improvement of standard of living without reversible damage to resources we need to survive as species (Lehrer 2001). Green design is intended to develop more environmentally benign products and processes. The application of green design involves a particular framework for considering environmental issues, the application of relevant analysis and synthesis, methods and a challenge to traditional procedures for design and manufacturing (hendrichson, Conway - Schempt, Lave and McMicheal, Undated). The green approach to architecture is not something new as it has existed for years. What is new is the realization that green approach to the built environment involves a holistic approach to the design of buildings; that all the resources that go into a building, be they materials, fuels or the contribution of the users need to be considered if sustainable architecture is to be produced (Brende and Vale 2007).

In Nigeria some buildings embody one of the various verifiable characteristics of green design. Buildings with holistic approach are yet to be seen. Sustainable development is the challenge of meeting growing human needs for natural resources, industrial products, energy, food, transportation and effective waste management while conserving and protecting environmental quality and the natural resource base essential for future life and development. This concept recognizes that meeting long term human needs will be impossible unless we also conserve the earth's natural, physical and chemical system (Gottfried, 1996). This is also in tandem with environmental sustainability. There is no doubt that sustainable development concepts, applied to the design, construction and operation of buildings can enhance both the economic welfare and environmental health of communities in Nigeria and other third world countries. This is more apt in this era of climate change. Sustainable development emerged most strongly in the environmental context. However, the evolution of the concept in the 1990's to encompass the economic, social and environmental points of view made the concept a driving force. The economic point deals with growth, efficiency and stability. The social aspect is concerned with poverty, cultural heritage and empowerment while the environmental aspect deals with biodiversity/resilience natural resources and pollution (Nwafor, 2006)

Embracing green or sustainable concept in design is aimed at reducing energy, operation and maintenance cost, reduced building related illness, increase the productivity and comfort of building occupants; reduce waste and pollution and increase building and component durability and flexibility. It is important that the focus of green concept be embraced from the early stages of building design, planning and construction. According to Gottfried (1996) the decision made at the first phase of building design and construction can significantly affect the costs 
and efficiencies of other phases as recent studies have shown that green building measures taken during construction or renovation can result in significant building operational savings, as well as increases in employee productivity. In essence, building related costs are best revealed and understood when they are analyzed over the life span of the building. In Nigeria, Green concept, sustainability and environmental issues are hardly put into consideration when designing a new building or renovating an old one. These results in a short fall in user satisfaction, functional space planning and service type. In addition sustainable building components are often neglected during design and construction.

In Nigeria, the first bank head office located in Marina Lagos was designed without taking tropical climate into consideration. The design would have been more appropriate for temperate countries like the United Kingdom or France as provision was not made for natural ventilation and lighting. Whenever power from the main grid (public electricity) fails and by any act of the devil, electricity generators develop operational challenges, everywhere will be in darkness and the entire workplace will be suffocating.

In some estates like dolphin, the level of natural lighting and ventilation leaves much to be desired. It is equally very surprising that some buildings in Environmental science faculties of some universities are not given the touch of green or ecological sustainability in their design and construction.

This paper aims at highlighting the need for green and sustainable design in Nigeria, using Lagos as a case study. This will be achieved through the following objectives:

To determine the effect of green design on environmental sustainability including its economic implication

To determine the level of green design element appreciation of occupiers through their value hierarchy preferences of building services/components

To determine if the energy situation in the study area provides incentives for green design to achieve energy savings.

\section{Literature}

According to Lehrer (2001), to work towards creation of sustainable development, one must understand the environmental impacts of buildings and their relative importance. The most and best understood impact is caused by energy used in building operations.

The primary energy loads in buildings are created by lighting, space heating, cooling equipments and domestic hot water. The production and consumption of this energy contributes to air pollution, acid rain and global climate change.

Udechukwu and Johnson (2008) describes green buildings as a generic term that generally refers to the practice of increasing the efficiency and performance of building through better sitings, designs, construction, operation and maintenance. They (Udechukwu and Johnson) further submitted that conventional construction methods have been linked to environmental damage, including depletion of natural resources, air and water pollution, toxic waste and global warming. Conventional buildings have a significant impact on the environment including wetland depletion and deforestation (Otegbulu 2007)

Conventional construction methods do not take sustainability into consideration and are not environmentally friendly. The method is not able to strike a balance between environmental social and economic considerations.

\section{Dimensions of Green Design and Environmental Sustainability}

Dimensions of green design include; energy efficiency, water efficiency, waste reduction, building operation, construction, maintenance, occupant health and productivity, stormwater management, climate and environmental integration (Sustainable neighborhood). The study of green design goes beyond the physical building itself but extend to environmental interactions. Green building characteristics overlap with many other neighborhood elements, installation of water conserving features, recovery of non - sewage waste water and use of pervious pavings around buildings. These have obvious implications for the design of water, wastewater and storm water infrastructure respectively. The use of vegetation in neighborhood design also overlaps; trees shade buildings and shield them from wind while green roof buildings may both reduce storm water runoff and provide evaporative cooling. Furthermore, the potential for energy efficient buildings may both reduce storm water runoff and provide evaporative cooling (Engel - Yan, Kennedy, Saiz and Pressnand 2005).

In most Nigerian cities, environmental considerations are not considered in community design. For instance, Dolphin Estate Lagos is built on reclaimed wetland and the unbuilt area fully covered with interlocking concrete and asphalt in some areas without adequate drainage. This result to extensive flooding that takes between $8-96$ hours to drain. Developed estates are devoid of shades resulting in hostile micro-climatic conditions. Trees and vegetation have been used in cities for hundreds of years to positively influence the urban micro - climate. Some of the dimension of Green design in relation to environmental sustainability will be discussed below.

\section{Energy Efficiency}

Gottfried (1996) submits that 50\% of the energy used in a building is devoted to producing an artificial indoor climate through heating, cooling, ventilation and lighting. According to the author, a typical building energy's 
bill constitutes approximately 25 percent of building's total operating costs in the United States. However, estimates indicate that climate - sensitive design with the use of appropriate and available technologies could cut heating and cooling energy consumption by 60 percent. Heating is however not important in tropical climate regions like Nigeria where cooling is mostly required. The design of the building must reflect consideration directed towards reduction in energy cost

Federer in (Engel - Yan et al 2005) describes the effect of trees in modifying the urban microclimate, which affects both comfort and building space conditioning energy use. Microclimatic temperature is affected by radiation, convection and evaporative cooling. Trees affect microclimate through their effect on these processes. Federer considers shading to be the most important method by which trees affect the microclimate. Simpson and McPherson (2001) gave several recommendations for locating urban trees to maximize energy saving in several regions of the United States. They are of the view that east and west orientation provides shades when sun angles are lower and conclude that larger trees should be used to maximize benefits. They did find that except for southerly orientated trees, energy savings are generally inversely proportional to tree - building distances. They concluded that factors such as climate conditions, electricity emissions factors, building construction and tree growth rates, must be considered in energy savings and carbon dioxide emission reduction calculation. Trees abound in Nigeria but most often building sites are cleared of all vegetation (trees) and covered with asphalt or concrete which often have adverse environmental consequences. Energy could also be saved through provision of natural ventilation and lighting in building design. This can be achieved through proper positioning of windows and perforated walls in appropriate parts of the building. In some types of buildings this can be achieved through roof ventilation using cold multi - functional ventilators. Energy saving through natural ventilation and lighting could further be enhanced through wide windows and external doors and good material choice in window design like glazed windows of different brands (Fulleton 1978, Hachler, Holderen 2008; and Lippiatt and Norris 1996).

Electrical appliances and fittings incorporated into building design should be energy efficient. There is therefore the need to get the most useful output from energy sources. At this point, it is necessary to explain that energy efficiency of a device is a comparison, or ratio, of the useful energy output. This ratio is always related to the particular circumstance (the season, timing, desired end result e.t.c.). For example, a typical incandescent bulb converts only $10 \%$ of input electrical energy into light energy, the rest goes into heat. The efficiency in this case is $10 \%$. If many light bulbs are turned on at the same time, there will be need to turn on the air conditioners to provide a cooling effect in the room, which implies more inefficiency. Under very cold or winter conditions, it will be efficient to use incandescent bulb as the heat provided will likely reduce the need for heaters in temperate areas (DeGunther, 2008).

According to Shomolu (2006), many homes in Nigeria are built without due regard for energy conservation. Things will have to change when power reform fully takes root and people are made to pay full value for the electricity they consume. If we use Lekki Phase 1(a low density area of Lagos) with at least 2000 homes presently occupied with an average of 75 lamps per household (internal and external, servant's quarters, e.t.c.) as an example, there will be at least 150000 lamps in the estate. Most likely they will be the old fashioned energy wasteful incandescent bulb types with ratings of 60 watts and 100 watts.

Household lighting alone will thus be accounting for between 9,000,000 watts and 15,000,000 watts, i.e 9MW or $15 \mathrm{MW}$. By replacing all the lamps with the more modern and more efficient, "energy Saver" lamps now easily available in the market, the lightning load in the estate can be reduced to between 750,000 watts and 3,000,000 watts, i.e between $0.75 \mathrm{MW}-3 \mathrm{MW}$. This probably would eliminate load - shedding within the estate. On a national scale, more MW capacity would be released to supply more continuous power to more customers. This will reduce the number of power stations required in the country.

\section{Stormwater Management}

Poor stormwater management could lead to flooding in urban areas. This could adversely affect the sustainability of the urban environment. According to Engel-Yan et al (2005), high levels of stormwater runoff in urban areas cause many environmental and economic problems including water pollution, flooding and erosion. Different measures are taken by planners to enhance environmental sustainability through stormwater management. The principle of stormwater source control is to manage rainwater at its source, instead of discharging it into conventional, combined or separated sewer systems. The urban forest helps to mitigate the negative impact of stormwater through double fold process. The first is that trees intercept and store rainfall on leaves and branch surfaces which helps in alternating runoff volume and delays the onset of peak-flows. Secondly, root growth and decomposition enhances the capacity and rate of soil to absorb or infiltrate rainfall and minimize overland flow. Other methods of stormwater management include; provision of infiltration basins, retention ponds, infiltration tranches, porous paving with reservoir structure e.t.c (Martin, Ruperd and Legret (2007); Engel - Yan et al (2005)). 


\section{Construction}

Materials flow and cycle is a technique for tracing material use and location over time. For example, steel is routinely recovered from demolished buildings and other products such as automobiles, melted and re-used in close recycle loop. Some materials are disposed into landfills. These materials can equally be recovered and reused (Hedrickson et-al undated).

Application of green buildings and concepts can yield savings during the construction process. Measures that are readily easy to implement can result in savings to the contractor or developer. Some of these include; lower energy by monitoring usage, and installing energy efficient lamps, lower water costs by monitoring consumption and using storm water, lower material costs with more careful purchase and re-use of resources and materials among others.(Gottfried,1996).

Designing and manufacturing green products require appropriate knowledge, tools, production methods and incentives. These design tools will help identify design changes that have lower costs while improving material use and recyclability (Hendrickson 2008 and Roberts 2007).

\section{Study Area}

The study Area is metropolitan Lagos - Nigeria. Lagos was the former capital of Nigeria until 1991. It still remains the commercial capital of the country. According to 2006 National census, its total population stands at $9,014,534$ people. This data is however being disputed by the Lagos State government who put the population at $17,552,942$.

The land area of metropolitan Lagos is approximately $999.6 \mathrm{~m}^{2}$. It has twenty (20) local government councils out of which seventeen (17) falls within metropolitan Lagos. The metropolitan area has a population of 7,937,932 and 15,532 households.

The particular areas studied in the area include Dolphin Estate (low - medium density) sharing boundary with Ikoyi Lagos, and Abraham Adesanya Estate (medium density) along Lekki - Epe axis Lagos.

Dolphin estate comprised of duplexes and flats. The flats are in the lower part of the estate. Abraham Adesanya estate is mainly comprised of duplexes. Dolphin Estate is a high income estate located within the Lagos Island area while Abraham Adesanya Estate is located at the outskirts of Lagos.

Dolphin estate has an almost impervious covering around the buildings which does not allow fast drainage of storm water. Questionnaires were also administered to eight other local government areas including; Alimosho, Apapa, Eti - osa, Ikeja, Kosofe, Mushin, Mainland and Surulere to generate data on the use of generators in the study area.

\section{Research Method}

The study is a survey research and fact finding. It was designed to determine the level of compliance by households to green design and environmental sustainability. The study targeted only residential households in the study area. In adopting a survey for this study two structure questionnaires were prepared for Dolphin and Abraham Adesanya estates and another for the eight metropolitan local government areas in Lagos. In Dolphin estate, there are 882 duplex houses (441 blocks) and 621 flats. Questionnaires were distributed to 65 households in the duplexes and 55 households in the flats making a total of 120.46 responded in each case, with a total of 96 responses. In Abraham Adesanya estate, questionnaires were distributed to 150 households out of which 91 responded. In both estates questionnaires were addressed to head of households. The sample size was drawn from the study population. For instance, Dolphin estate has a total of 1503 households out of which a sample of 120 households was selected randomly. This represents about $8 \%$ of the study population. In Abraham Adesanya Estate, there are 1000 households in the estate from which a sample of 150 households was randomly drawn. This is approximately $15 \%$ of the population.

The 8 metropolitan local government areas have a population of 7,633 households from which a sample of 1040 was drawn. This represents $13.62 \%$ of the population

The questionnaire on Dolphin estate is designed to find the effect of lack of Green design in the covering around the buildings where everywhere is covered with interlocking concrete without regard that it is a reclaimed wetland. The questionnaire was used to verify the duration of flooding after rain and cost of damage to household assets as a result of the prolonged flooding.

With regard to Abraham Adesanya estate the questionnaire is designed to investigate household preferences with respect to ventilation and natural lighting. The study also extends to the use of generators as an alternative source of energy through questionnaires administered to 1040 households in the eight local governments in the study area with 774 respondents. Analysis was carried out with the use of descriptive statistics including relative impact index. The economic impact of flooding was calculated by multiplying the mean cost of damage per household with the total number of households in Dolphin Estate (using cost approach) 


\section{Data Presentation and Analysis}

\section{Table1: Flood Duration}

From table 1 the average duration for storm water to drain after heavy rainfall is 2.56 days for households living in the Duplex houses and 4days for households living in flats. The Gap in duration is due to the fact that the estate is sloppy. The flats are located at the lower part of the slope. The situation is so bad that in critical situations residents have to use canoes to cross to the road.

This problem affects the productivity of residents of the estate. In effect, residents of duplex houses and flats loose 2,205 and 2,402 man hours respectively each time there is heavy rainfall. In addition, the prolonged period of the flood could affect the building fabric and increase damage to furniture. There could also be the risk of electrocution.

\section{Table 2: Economic impact of flood on households}

The average loss or damage on property caused by the flooding in flats is N157,655.25 while that of the duplex is N272,500.00. This could be explained by the fact that people staying in the duplex area are richer and have more valuable assets. The figures above indicate the economic impact of the flooding in the study area due to lack of green/sustainability consideration in the design. This is also adverse to environmental sustainability. The total cost of flood related damage on their asset is N338,248,755 (N240,345,000 for duplex houses and N97,903,755 for flats). This is based on the average loss multiplied by the number of households. For the developers (Government) to allow the situation to persist is a mark of bad governance.

\section{TABLE 3: Preference Hierarchy for Building Services/Component (Residential Development)}

From table 3 there is evidence that due to the poor power situation in the country, residents of the estate don't have very high preference for natural ventilation and lighting as both ranked $5^{\text {th }}$ and $7^{\text {th }}$ respectively. The positions of the preferences however indicated that some of the respondents may not understand the link between natural ventilation and lighting and energy savings. If they do, the situation may alter. It is also important to note that availability of water and use of household appliances in homes depend on the availability of electricity

\section{TABLE 4: Number of Hours of Electricity Supply per day}

Data from table 4 shows that majority of households in the study area have electricity power supply between 1-5 hours a day more particularly Kosofe (62.8\%), Mainland (60\%), Apapa (50\%), Alimosho (40\%), Mushin (34\%) and Surulere (32.3\%). Some do not even have power supply for some days. This is a serious problem considering the socio-economic importance of electricity to urban households. Poor electricity infrastructure provides an incentive for resorting to informal sources of power supply which has adverse implication to the environment and its sustainability. In addition households cannot store food and perishable items.

\section{TABLE 5: Ownership of Private Electricity generator and TABLE 6: Frequency of use of electricity} generator

From table 5 , it could be seen that between $60 \%$ and $92 \%$ of households in the study area use private electricity generators as alternative power supply. Some of these generators are substandard and cause air pollution. Data from table 6 indicates the frequency of usage. The highest frequency of usage is in Eti - osa local government area $(91.9 \%)$ followed by Alimoso local government (80.4\%). Households should therefore be encouraged to use inverters in their homes which can partly be financed with money used in buying and fueling generators. Frequent use of these generators have obvious implications which includes defacing of building walls and premature death from inhalation of carbon monoxide and global warming

\section{Findings}

Dolphin estate has been experiencing severe flooding which has been causing damage to property and building fabric

Flooding in Dolphin estate constrains movement and delays vehicular and pedestrian movement which leads to loss of productive man hours.

Ventilation and natural lighting are not very high in households' ranking in Abraham Adesanya estate as they ranked $5^{\text {th }}$ and $7^{\text {th }}$ respectively, this is an indication of how low households perceive the importance of green and sustainable design in a tropical climate like Nigeria

The power supply situation in Lagos is deplorable and most households experience power supply for a few hours per day leading to multiple ownership of electricity generators, most of which are substandard and major causatives of global warming

Resort to informal source of power supply is fraught with different risks including respiratory and suffocation problems, defacing of building walls and fire incidences. Also, regular supply of pipe borne water is directly linked to availability of electricity supply 


\section{Recommendations}

Drainage system in the estate (Dolphin) should be improved to minimize the incidence and duration of flood while the mistakes in dolphin Estate Should be avoided in future developments.

Households should be compensated for damage to their property due to flood if the disaster is due to government inaction

Awareness should be created among Nigerians on the importance of green and sustainable design in their homes and places of work

The power situation in the country should be given urgent and serious attention to reduce the resort to informal power sources which contribute to global warming.

The use of renewable energy and a holistic adoption of green design should be encouraged in the country to minimize the impact of non-environmentally sustainable practices.

Government should include in their power policy incentives to encourage energy efficiency instead of building more power stations

\section{Discussion and Conclusion}

Like the design process, the design of green buildings and sustainable environment involves creative arrangement of components and details to meet a set of specifications/guidelines subject to other constraints. Results from the table indicate that Nigerians are not green conscious in building design and environmental management. The rampant use of generators most of which are substandard instead of adoption of natural ventilation and lighting in their design is a practical indication of a nation which is not conscious of the link between environment, good health and economic development. The amount of man hours lost due to flooding and damage to households' property constitute a serious problem to both government and households. In order to avert a gloomy future for our environment, there is need to reduce to bare minimum the use of non - renewable resources, manage renewable resources to achieve sustainability and reduce with the ultimate goal of eliminating toxic and otherwise harmful emissions to the environment including emissions contributing to global warming.

\section{References}

Brenda and Vale R. (2006). Principles of Green Architecture in Stephen M, Wheeler and Beatley T. Ed (2006). The Sustainable Urban Development.

Burberry, P. (1997). Mitchell's Building Series, Environment and Services, Henry Ring Ltd, Great Britain.

Degunter, R. (2008). Energy Efficient Homes for Dummies, Willey Publishing Inc. Indiana.

Engel-Yan, J. Kennedy, C. Saiz, Bressnail, K. (2005). Towards sustainable Neighbourhoods: The need to consider infrastructure interactions. Journal of Civil Engineering. Vol 32. 2005, NRC Canada.

Federer C.A. (1970). Effect of Trees in Modifying Urban Micro - Climate, Symposium on Trees and Forests in an Urbanizing environment, Amherst Mass, $18-21$ August, Cooperative extension service, University of Massachusetts, Amherst mass; 23 - 28

Fullerton R.L. (1978). Building Construction in Warm Climates, Oxford University Press U.K

Gottfried D.A. (1996). The Economics of Green Buildings (1996) in Sustainable Technical Manual, Public Technology Inc. U.S.A.

Hackler J and Holden J.P. (2008). Design and Performance of an Award - Winning Green Head quarters Journal of Green Building. Vol.3 No 1, winter 2008.

Hendrickson, C, Schempt, N.C., Lave L, McMichael F. (undated). Introduction to Green Design, Green Design institute, Carnegie Mellon University, Pittsburgh P.A

Lehrer, D: Sustainable Design Teicholz E. (2001). Facility Design and Management Handbook, McGraw - Hill New-York

Lippiatt B.C, and Morris G.A. (1996). Selecting Environmentally and Economically Balanced Building Materials in Sustainable Technical Manual, Public Technology Inc. U.S.A.

Martin C, Ruperd. Y, Legret, M. (2007). Urban Stormwater Management: The Development of Multi-criteria Decision Approach for Best Management Practices, European Journal of Operational Research, No 181, pg 338-349, Elsevier

Nwafor, J.C. (2006). Environmental Impact Assessment for Sustainable Development, Eldermark Publishers, Enugu Nigeria

Otegbulu A.C. (2005). Capturing the Hidden Values of Urban Wetlands as a Strategy for Sustainable Wetland Development, Proceedings of the $35^{\text {th }}$ Annual Conference of the Nigerian Institution of Estate Surveyors and Valuers; on Development of Nigerian Wetlands; $5^{\text {th }}$ April $-10^{\text {th }}$ April 2005; $42-51$ 
Otegbulu A.C. (2006). An Assessment of User Demand Preferences of Urban Infrastructure in Lagos Metropolis Using Contingent Valuation Model: PhD Thesis Submitted to The Faculty of Environmental Science, Enugu State University of Science and technology Enugu, Nigeria

Otegbulu, A.C, Osagie, J.U. and Famuyiwa F. (2009). A Value Hierarchy Study of Building Services/Components in Commercial and Residential Developments: A Comparative Analysis, Proceedings of the $25^{\text {th }}$ Annual Conference of Association of Researchers in Construction Management, 7 - 9 September 2009, Albert - Hall Nottingham; 1993 - 1200

Roberts T. (2007). Historic Preservation of Green Buildings: A Lasting Relationship, Environmental Building News, January 2002.

Shomolu, F.A. (2006). The Power Sector Reform and Urban Transportation, Proceedings the $36^{\text {th }}$ Annual Conference of the Nigerian Institution of Estate Surveyors and Valuers, Minna, $27^{\text {th }}$ March $-1^{\text {st }}$ April 2006; 1-6

Simpson, J.R., and McPherson, E.G. (2001). Tree Planting to Optimize Energy and $\mathrm{Co}_{2}$ Benefits, Proceedings of the 2001 Urban forest Conference, Washington D.C, 5 - 8 September 2001, American Forest Washington D.C; $81-84$

Soderbaum, P. (2008). Understanding Sustainability in Economics, Earthscan London.

Udechukwu C.E and Johnson. O.O. (2008). The Impact of Green Buildings on Valuation Approaches, Lagos Journal of Environmental Studies, Vol.6, No.1; 3-13.

Table 1. flood duration

\begin{tabular}{|c|c|c|c|c|c|c|c|}
\hline \multirow{6}{*}{ DUPLEX } & Duration & frequency & percentage & \multirow{6}{*}{ FLATS } & Duration & Frequency & Percentage \\
\hline & Less than a day & 22 & 45.83 & & Less than a day & 5 & 10.87 \\
\hline & $\begin{array}{ll}\text { Between } & 1-2 \\
\text { days }\end{array}$ & 8 & 16.67 & & $\begin{array}{ll}\begin{array}{l}\text { Between } \\
\text { days }\end{array} & 1-2 \\
\end{array}$ & 5 & 10.87 \\
\hline & $\begin{array}{lll}\begin{array}{l}\text { Between } \\
\text { days }\end{array} & 2 & -4 \\
\end{array}$ & 4 & 8.33 & & $\begin{array}{lll}\begin{array}{l}\text { Between } \\
\text { days }\end{array} & 2 & -4 \\
\end{array}$ & 10 & 21.74 \\
\hline & $\begin{array}{ll}\text { Between } & 4-7 \\
\text { days }\end{array}$ & 12 & 25 & & $\begin{array}{ll}\text { Between } & 4-7 \\
\text { days }\end{array}$ & 26 & 56.52 \\
\hline & Total & 46 & 100 & & Total & 46 & 100 \\
\hline
\end{tabular}

Source: Field survey 2009

Table 2. Economic impact of flood on households

\begin{tabular}{|c|c|c|c|c|c|c|c|}
\hline \multirow{7}{*}{ FLATS } & $\#$ & frequency & percentage & \multirow{7}{*}{ DUPLEX } & $\#$ & Frequency & Percentage \\
\hline & $10,000-100,000$ & 19 & 59.38 & & $\begin{array}{l}10,000 \\
100,000\end{array}$ & 1 & 5.26 \\
\hline & $\begin{array}{l}100,000 \\
200,000 \\
\end{array}$ & 4 & 12.5 & & $\begin{array}{l}100,000 \\
200,000\end{array}$ & 6 & 31.58 \\
\hline & $\begin{array}{l}200,000 \\
300,000\end{array}$ & 1 & 3.13 & & $\begin{array}{l}200,000 \\
300,000\end{array}$ & 2 & 10.53 \\
\hline & $\begin{array}{l}300,000 \\
400,000\end{array}$ & 1 & 3.13 & & $\begin{array}{l}300,000 \\
400,000\end{array}$ & 3 & 15.79 \\
\hline & Above 400,000 & 7 & 21.88 & & Above 400,000 & 6 & 31.58 \\
\hline & Total & 32 & 100 & & Total & 18 & 100 \\
\hline
\end{tabular}

Mean damage $=\mathrm{N} 1557,656$

Mean damage $=272,500$

Source: Field survey 2007 
Table 3. Preference Hierarchy for Building Services/Component (Residential Development)

\begin{tabular}{|c|c|c|}
\hline Variables & Relative Index & Ranks \\
\hline Constant Electricity & 0.912 & 1 \\
\hline Reliable Water & 0.900 & 2 \\
\hline Amount of space & 0.899 & 3 \\
\hline External/internal design & 0.849 & 4 \\
\hline Window type/ventilation & 0.771 & 5 \\
\hline Floor finishing & 0.752 & 6 \\
\hline Natural lighting & 0.744 & 7 \\
\hline Wall finishing & 0.723 & 8 \\
\hline Security & 0.721 & 9 \\
\hline Mobile phone reception & 0.716 & 10 \\
\hline Parking space & 0.708 & 11 \\
\hline Toilet quality & 0.708 & 12 \\
\hline Archiving/Storage facilities & 0.699 & 13 \\
\hline Elevator/lift & 0.654 & 14 \\
\hline
\end{tabular}

Source: field survey 2009

Table 4. Number of Hours of Electricity Supply per day

\begin{tabular}{|c|c|c|c|c|c|c|c|}
\hline & \multicolumn{6}{|c|}{ On the average, how many hours do you enjoy electricity supply a day? } & \multirow[b]{2}{*}{ Total } \\
\hline & $1-5$ hours & 6-10 hours & $11-15$ hours & 16-20 hours & 24 hours & None for some days & \\
\hline \multirow[t]{2}{*}{ ALIMOSHO } & 38 & 41 & 4 & 5 & 0 & 7 & 95 \\
\hline & 40.0 & 43.2 & 4.2 & 5.3 & 0.0 & 7.4 & $100 \%$ \\
\hline \multirow[t]{2}{*}{ APAPA } & 30 & 20 & 10 & 0 & 0 & 0 & 60 \\
\hline & 50.0 & 33.3 & 16.7 & 0.0 & 0.0 & 0.0 & $100 \%$ \\
\hline \multirow[t]{2}{*}{ ETI-OSA } & 27 & 0 & 17 & 6 & 2 & 19 & 100 \\
\hline & 27.0 & 0.0 & 17.0 & 6.0 & 2.0 & 19.0 & 100.0 \\
\hline \multirow[t]{2}{*}{ IKEJA } & 24 & 21 & 13 & 13 & 3 & 9 & 83 \\
\hline & 28.9 & 25.3 & 15.7 & 15.7 & 3.6 & 10.8 & $100 \%$ \\
\hline \multirow[t]{2}{*}{ KOSOFE } & 54 & 19 & 3 & 2 & 0 & 8 & 86 \\
\hline & 62.8 & 22.1 & 3.5 & 2.3 & 0.0 & 9.3 & $100 \%$ \\
\hline \multirow[t]{2}{*}{ MAINLAND } & 60 & 30 & 0 & 0 & 0 & 10 & 100 \\
\hline & 60.0 & 30.0 & 0.0 & 0.0 & 0.0 & 10.0 & $100 \%$ \\
\hline \multirow[t]{2}{*}{ MUSHIN } & 33 & 38 & 8 & 1 & 0 & 17 & 97 \\
\hline & 34.0 & 39.2 & 8.2 & 1.0 & 0.0 & 17.5 & $100 \%$ \\
\hline \multirow[t]{2}{*}{ SURULERE } & 31 & 32 & 14 & 0 & 0 & 19 & 96 \\
\hline & 32.3 & 33.3 & 14.6 & 0.0 & 0.0 & 19.8 & $100 \%$ \\
\hline
\end{tabular}

Source: Field survey 2009. 
Table 5. Ownership of Private Electricity generator

\begin{tabular}{|c|c|c|c|}
\hline & \multicolumn{3}{|c|}{ Do you have a standby generator } \\
\hline & YES & NO & Total \\
\hline ALIMOSHO & 78 & 19 & 97 \\
& 80.4 & 19.6 & $100 \%$ \\
\hline APAPA & 60 & 10 & 70 \\
& 85.7 & 14.3 & $100 \%$ \\
\hline ETI-OSA & 91 & 8 & 99 \\
& 91.9 & 8.1 & 100 \\
\hline IKEJA & 72 & 16 & 89 \\
& 81.8 & 18.2 & $100 \%$ \\
\hline KOSOFE & 68 & 17 & 85 \\
& 80.0 & 20.0 & $100 \%$ \\
\hline MAINLAND & 50 & 30 & $100 \%$ \\
\hline MUSHIN & 62.5 & 37.5 & 94 \\
& 51 & 43 & $100 \%$ \\
\hline SURULERE & 54.3 & 45.7 & 94 \\
& 58 & 36 & $100 \%$ \\
\hline
\end{tabular}

Source: Field survey 2009.

Table 6. Frequency of use of electricity generator

\begin{tabular}{|c|c|c|c|c|c|c|}
\hline & \multicolumn{5}{|c|}{ If your answer to 28 above is yes, how often do you use it? } & \multirow[b]{2}{*}{ Total } \\
\hline & Daily & $\begin{array}{c}\text { 1-3 times a } \\
\text { week }\end{array}$ & $\begin{array}{c}\text { 4-7 times a } \\
\text { week }\end{array}$ & $\begin{array}{l}\text { Once in a } \\
\text { long while }\end{array}$ & Others & \\
\hline ALIMOSHO & $\begin{array}{c}57 \\
73.1 \% \\
\end{array}$ & $\begin{array}{c}11 \\
14.1 \%\end{array}$ & $\begin{array}{c}6 \\
7.7 \% \\
\end{array}$ & $\begin{array}{c}3 \\
3.8 \% \\
\end{array}$ & $\begin{array}{c}1 \\
1.3 \\
\end{array}$ & $\begin{array}{c}78 \\
100 \% \\
\end{array}$ \\
\hline APAPA & $\begin{array}{c}50 \\
83.3\end{array}$ & $\begin{array}{c}10 \\
16.7\end{array}$ & $\begin{array}{c}0 \\
0.0\end{array}$ & $\begin{array}{c}0 \\
0.0\end{array}$ & $\begin{array}{c}0 \\
0.0\end{array}$ & $100 \%$ \\
\hline ETI-OSA & $\begin{array}{c}75 \\
82.4\end{array}$ & $\begin{array}{c}8 \\
8.8 \\
\end{array}$ & $\begin{array}{c}7 \\
7.7 \\
\end{array}$ & $\begin{array}{c}1 \\
1.1 \\
\end{array}$ & $\begin{array}{c}0 \\
0.0\end{array}$ & $\begin{array}{c}91 \\
100 \\
\end{array}$ \\
\hline IKEJA & $\begin{array}{c}28 \\
40.0\end{array}$ & $\begin{array}{c}24 \\
34.3\end{array}$ & $\begin{array}{c}14 \\
20.0\end{array}$ & $\begin{array}{c}4 \\
5.7\end{array}$ & $\begin{array}{c}0 \\
0.0\end{array}$ & $\begin{array}{c}70 \\
100\end{array}$ \\
\hline KOSOFE & $\begin{array}{l}454 \\
67.2 \\
\end{array}$ & $\begin{array}{c}9 \\
13.4 \\
\end{array}$ & $\begin{array}{c}12 \\
17.9 \\
\end{array}$ & $\begin{array}{c}1 \\
1.5 \\
\end{array}$ & $\begin{array}{c}0 \\
0.0\end{array}$ & $\begin{array}{c}67 \\
100 \% \\
\end{array}$ \\
\hline MAINLAND & $\begin{array}{c}30 \\
60.0\end{array}$ & $\begin{array}{c}10 \\
20.0\end{array}$ & $\begin{array}{c}10 \\
20.0\end{array}$ & $\begin{array}{c}0 \\
0.0\end{array}$ & $\begin{array}{c}0 \\
0.0\end{array}$ & $\begin{array}{c}50 \\
100 \%\end{array}$ \\
\hline MUSHIN & $\begin{array}{c}33 \\
67.3 \\
\end{array}$ & $\begin{array}{c}3 \\
6.1 \\
\end{array}$ & $\begin{array}{c}11 \\
22.4 \\
\end{array}$ & $\begin{array}{c}2 \\
4.1 \\
\end{array}$ & $\begin{array}{c}0 \\
0.0\end{array}$ & $\begin{array}{c}49 \\
100 \% \\
\end{array}$ \\
\hline SURULERE & $\begin{array}{c}39 \\
66.1\end{array}$ & $\begin{array}{c}4 \\
6.8\end{array}$ & $\begin{array}{c}10 \\
16.9\end{array}$ & $\begin{array}{c}5 \\
8.5\end{array}$ & $\begin{array}{c}1 \\
1.7\end{array}$ & $\begin{array}{c}59 \\
100 \%\end{array}$ \\
\hline
\end{tabular}

Source: Field survey 2009 